\title{
Hematological parameters in shortnose guitarfish Zapteryx brevirostris Müller and Henle, 1841 (Chondrichthyes, Rhinobatidae)
}

\section{Parámetros hematológicos en guitarra shortnose Zapteryx brevirostris especies Müller y Henle, 1841 (Chondrichthyes, Rhinobatidae)}

\author{
Nathalia Barreto $B,{ }^{1}$ MV, Daniela Ferrer MV, ${ }^{2}$ Ph.D, Paula Baldassin,${ }^{3}$ Ph.D, \\ Denise Bobany $M,{ }^{2 *}$ M.Sc.
}

\begin{abstract}
${ }^{1}$ Veterinary Medical autonomous. ${ }^{2}$ University Center Serra dos Orgãos - UNIFESO - Center of Science for Health - Course of Veterinary Medicine - Estrada da Prata $s / n$-Teresópolis - RJ -Brasil - CEP: 25.976-340. ${ }^{3}$ Veterinary Medical from Aquário de Ubatuba - Rua Ponciano Eugênio Duarte, 203 Ubatuba -SP - Brasil - CEP: 11680-000.*Correspondence: debobany@gmail.com
\end{abstract}

Received: October 2014; Accepted: March 2015.

\begin{abstract}
Objective. In view of the deficiency of information in the area of clinical pathology of elasmobranchs, mainly of the physiological parameters, the aim of this work was to study hematological parameters of the Zapteryx brevirostris species. Materials and methods. Four specimens apparently healthy of Zapteryx brevirostris; three females and a male were used. These animals are all pertaining ones to the Aquarium of Ubatuba, São Paulo (Brazil). Results. The obtained average of hematological values for the Zapteryx brevirostris were: Red Blood Cells were - $0.96 \times 106 / \mu \mathrm{L}$, Packed Cell Volume - 24.3\% and White Blood Cells - $36.8 \times 103 / \mu \mathrm{L}$. Conclusion. Although the small N, which decreases the accuracy, this research has scientific value because the situation of vulnerability of Zapteryx brevirostris, suggesting other studies.
\end{abstract}

Key words: Clinical Pathology, elasmobranchs, hematology (Source: DeSC, BVS).

\section{RESUMEN}

Objetivo. En vista de la carencia de información en el área de patología clínica de los elasmobranquios, especialmente en lo que respecta a los parámetros fisiopatológicos, el objetivo de este trabajo fue et de obtener parámetros de la hematología de la especie Zapteryx brevirostris. Materiales y método. Cuatro animales clínicamente saludables de Zapteryx brevirostris; tres hembras y un macho fueron utilizados, todos procedentes del Acuario de Ubatuba, S. P. Resultados. Los valores promedio de hematología para el Zapteryx brevirostris fueron: glóbulos rojos - $0.96 \times 106 / \mu \mathrm{L}$, volumen de los hematíes - $24.3 \%$ y glóbulos blancos $36.8 \times 103 / \mu \mathrm{L}$. Conclusiones. A pesar de la pequeña N, que disminuye la precisión, la investigación tiene valor científico debido a que Zapteryx brevirostris es una especie vulnerable; sugiriendo otros estudios.

Palabras clave: Elasmobranquios, hematología, patología clínica (Fuente: DeSC, BVS). 


\section{INTRODUCTION}

Brazil has extraordinary richness related to marine animals. However, little is known about the biology of each one of its forms, mainly regarding aspects of the disease in these animals and about the interactions between pathogens and hosts in natural environments.

The study of rays is of ecological interest because the invasion of man in the sea, so predatory, has caused great impact on the marine ecosystem, interfering not only in reproduction and survival of the rays, but also of countless beings to live there. The appreciation of the study of species in danger of extinction or vulnerable is of great importance for the ecological balance (1).

The Elasmobranchs are of great importance in the trophic chain, by the fact that they are animals of top or near the top of the marine food chain, and the decrease in its abundance can cause imbalance in trophic interactions within the community (2).

Only two genera of rays are found in the Brazilian coast, Zapteryx and Rhinobatos being that the genus Rhinobatos contains two species: Rhinobatos horkelli and Rhinobatos percellens, while the genre Zapteryx contains a single species: Zapteryx brevirostris, named commonly by "lane-viola short guy" or "banjo" $(2,3)$.

It should be remembered that the species Zapteryx brevirostris is already considered vulnerable, as stated on the red list of Endangered Species, from 2006, the IUCN (International Union for Conservation of Nature and Natural Resources), and it takes 14 years to be able to have its population doubled (2).

Meet the blood values in order to obtain a better assessment of the State of health of animals is so important to the veterinary practitioner as are the history and physical examination of the animal, contributing to the diagnosis of possible changes caused by disease or other environmental factors.

Hematological tests are considered, although routines are still rare for fish. The few published works, mainly about the rays, are old, and the variables used in the studies as climate, geographic distribution, eating habits, destruction of natural habitats among others may have changed a lot since the preparation of same. These works provide fickle results regarding nomenclature, cellular differentiation, maturation and functioning of blood cells of fishes (4- 5).

Second Hrubec and Smith (4) hematological techniques used to mammals are generally applicable to fish with slight modifications and

\section{INTRODUCCIÓN}

Brasil tiene una extraordinaria riqueza relacionada con los animales marinos. Sin embargo, se conoce poco acerca de la biología de cada una de sus formas, principalmente en lo que se refiere a los aspectos de la enfermedad en estos animales y las interacciones entre los agentes patógenos y los huéspedes en entornos naturales.

El estudio de las rayas es de interés ecológico debido a que la invasión del hombre en el mar como depredador, tiene un gran impacto en el ecosistema marino interfiriendo no solo en la reproducción sino también en la supervivencia de las rayas, así como también en las innumerables especies que viven allí. El reconocimiento del estudio de las especies que se encuentran en peligro de extinción o que son vulnerables es de gran importancia para el equilibrio ecológico (1).

Los elasmobranquios son de gran importancia en la cadena trófica, por el hecho de ser animales de la parte superior o cerca de la parte superior de la cadena alimenticia marina y dado que la disminución de su presencia puede causar un desequilibrio en las interacciones tróficas dentro de la comunidad (2).

En la costa brasileña solo se encuentran dos géneros de rayas, Zapteryx y Rhinobatos, teniendo este último género dos especies: Rhinobatos horkelli y Rhinobatos percellens, mientras que el género Zapteryx tiene una sola especie: Zapteryx brevirostris, Ilamada comúnmente "viola-cara-curta" o "guitarra chica" $(2,3)$.

Se debe recordar que la especie Zapteryx brevirostris ya es considerada como vulnerable, según se indica en la Lista Roja de Especies Amenazadas de 2006 de la UICN (Unión Internacional para la Conservación de la Naturaleza y los Recursos Naturales), ya que tarda 14 años para duplicar su población (2).

Conocer los valores de los parámetros sanguíneos para hacer una mejor evaluación del estado de salud de los animales es tan importante para el médico veterinario como también lo son la historia y el examen físico del animal, lo que contribuye al diagnóstico de posibles cambios causados por enfermedades u otros factores ambientales.

Se considera realizar pruebas hematológicas a pesar de que algunas rutinas son poco frecuentes para peces. Las pocas investigaciones publicadas, principalmente sobre rayas, son antiguas y las variables utilizadas en los estudios como el clima, 
Stoskopf (6) reports that, until recently, the Hematology of fish was considered a technique post mortem.

The blood sample can be obtained by different ways; however, the caudal vein is used more often, even with the possibility of obtaining a sample straight from the heart (4).

The blood of rays easily suffers hemolysis, and therefore should be transferred immediately to a tube containing anticoagulant. The best results are obtained with 1 to $3 \mathrm{~mL}$ of blood in the syringe (4).

There are controversies regarding the type of anticoagulant to be used in the blood sample. A solution that combines two anticoagulant compounds, heparin and EDTA that seems to be more effective with Elasmobranch blood than either compound used individually (6).

Occasionally, if the fish is stressed, and the fish are very sensitive to manipulation, blood can clot even with the presence of blood thinner, and may not be visible in the tube, but preventing the correct count of thrombocytes and leucocytes (4).

Hrubec and Smith (4) state that the erythrocyte may vary with the different environments that the fish live and the water quality conditions, although these changes are not well characterized.

According to Smith et al (6), the count of leukocytes in hemocytometer is the best method to determine the total count of leukocytes of fish by eliminating the interference of the erythrocytes nucleus.

The aim of study was to investigate hematological parameters of Shortnose Guitarfish (Zapteryx brevirostris), evaluating the techniques of collection and staining.

\section{MATERIALS AND METHODS}

Study location. This study was done with animals housed since April 2007 in the Aquarium of Ubatuba, northern coast of São Paulo- Brazil, Latitude -23.4509, Longitude -45.0647, Altitude $2 \mathrm{~m}$ and the Koeppen Classification climate: Af.

Animals in the study. Four animals were used of the Zapteryx brevirostris species being three females and one male.

Procedures performed. Although adults, animals had small sizes and weighed less than a pound each, therefore, due to low body weight was only possible withdrawal of $0.1 \mathrm{ml}$ of blood for carrying out the examinations, contradicting the Hrubec and Smith (4) indication. The blood la distribución geográfica, los hábitos alimenticios, la destrucción de los hábitats naturales, entre otros, pueden haber cambiado significativamente desde cuando se realizaron. Estos trabajos proporcionan resultados inconstantes en cuanto a la nomenclatura, diferenciación celular, maduración y funcionamiento de las células sanguíneas de los peces (4-5).

Las segundas técnicas hematológicas de Hrubec y Smith (4) utilizadas en mamíferos se aplican generalmente a peces con ligeras modificaciones; Stoskopf (6) informa que hasta hace poco, la hematología de los peces se consideraba una técnica post mortem.

Es posible obtener muestras de sangre de diferentes maneras; sin embargo, se utiliza más a menudo la vena caudal, aun con la posibilidad de obtener una muestra directamente del corazón (4).

La sangre de las rayas fácilmente sufre hemólisis $y$, por lo tanto, se debe trasladar inmediatamente a un tubo que contenga un anticoagulante. Los mejores resultados se obtienen con 1 a $3 \mathrm{ml}$ de sangre en la jeringa (4).

Existe una controversia en cuanto al tipo de anticoagulante que se debe utilizar en la muestra de sangre. Una solución que combina dos compuestos anticoagulantes, heparina y EDTA (ácido etilendiaminotetracético), parece ser más eficaz con la sangre del elasmobranquio que el compuesto utilizado individualmente (6).

Ocasionalmente, si el pez se encuentra estresado y si es muy sensible a la manipulación, la sangre puede coagularse inclusive en presencia del anticoagulante, y puede no ser visible en el tubo, impidiendo el recuento correcto de trombocitos y leucocitos (4).

Hrubec y Smith (4) establecieron que los eritrocitos pueden variar con los diferentes entornos donde el pez vive y las condiciones de calidad del agua, aún cuando estos cambios no se encuentren bien caracterizados.

Según Smith y colaboradores (6), el recuento de leucocitos en el hemocitómetro es el mejor método para determinar la cantidad total de leucocitos en los peces al eliminar la interferencia en el núcleo de los eritrocitos.

El objetivo del estudio fue investigar los parámetros hematológicos del pez guitarra de nariz corta (Zapteryx brevirostris), evaluando las técnicas de recolección y de tinción. 
sample was collected by venipuncture, using a $1 \mathrm{ml}$ syringe (syringe of insulin BD brand) and a needle $13 \times 4.5 \mathrm{~mm}$, of the ventral part of the tail, where is located the caliber caudal vein, as indicate Hrubec and Smith (4) and Smith et al (6). The animal was placed in a box containing saltwater and oxygenation and the whole procedure was done with the animal contained physically without using any anaesthetic drug as can be seen in figures $1 A-1 B$. This procedure
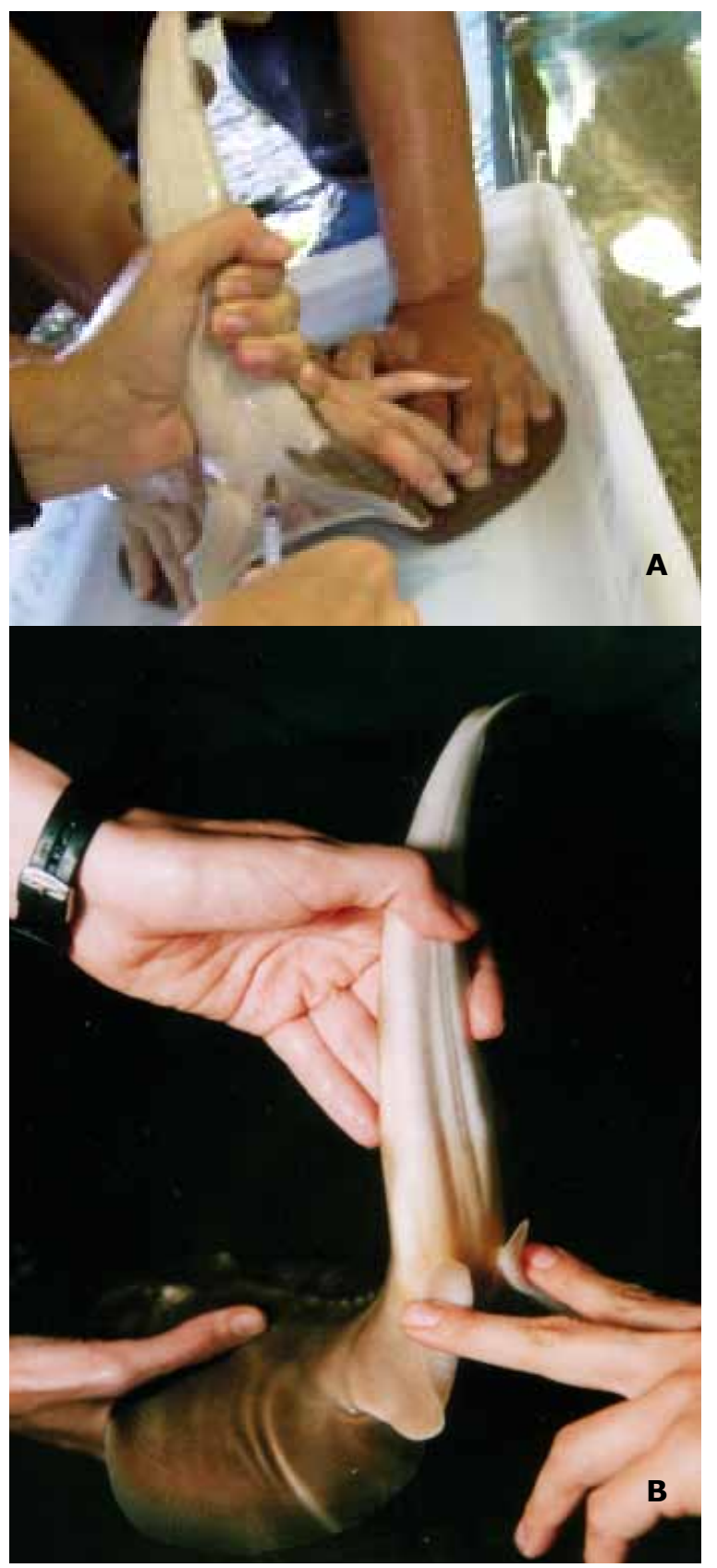

Figure 1. A. Blood collection of a male specimen of the Zapteryx brevirostris species obtained of the caudal vein. B. Ideal place for venipuncture.

\section{MATERIALES Y MÉTODOS}

Ubicación del estudio. Este estudio se realizó con animales albergados desde abril de 2007 en el Acuario de Ubatuba, costa norte de Sao Paulo, Brasil, Latitud -23.4509, Longitud -45.0647, Altitud $2 \mathrm{~m}$ y clasificación climática de Koppen: Af.

Animales en el estudio. Se utilizaron cuatro animales de la especie Zapteryx brevirostris, tres hembras y un macho.

Procedimientos realizados. Aunque adultos, los animales tenían tamaños pequeños y pesaron menos de una libra cada uno, por lo tanto, debido al bajo peso corporal, solo fue posible retirar 0,1 $\mathrm{ml}$ de sangre para realizar los exámenes, lo que contradice la indicación de Hrubec y Smith (4). La muestra de sangre se recogió por punción venosa, utilizando una jeringa de $1 \mathrm{ml}$ (jeringa de insulina de marca BD) y una aguja de $13 x$ 4,5 $\mathrm{mm}$, en la parte ventral de la cola, donde se encuentra la vena caudal, como lo indican Hrubec y Smith (4) y Smith y colaboradores (6). El animal se colocó en una caja con salmuera y oxigenación y todo el procedimiento se realizó manteniendo el animal en el contenedor sin utilizar ningún anestésico, como puede verse en las figuras $1 \mathrm{~A}$ y $1 \mathrm{~B}$. Este procedimiento causa estrés, lo que puede afectar los resultados obtenidos.

Inmediatamente después de la punción venosa, la sangre se trasvasó a un Eppendorf (Axygen) que contenía ácido etildiaminotetraacético (EDTA) (EDTA Vacutainer BD 26). Después de la homogenización de la sangre con anticoagulante y la identificación del Eppendorf, las muestras se procesaron en dos lugares: el recuento completo se realizó en una Cámara de Neubauer (Böco, Alemania) en el Acuario de Ubatuba y volumen de hematocritos se envió a un laboratorio privado de la ciudad, llamado MedLabor.

Utilizando las técnicas estándar, se realizó el eritrograma con la determinación de glóbulos rojos (hemocitómetro) y hematocritos (microhematocrito) y el leucograma, determinando únicamente los glóbulos blancos mediante la técnica desarrollada por Smith y colaboradores (6).

Aspectos éticos. Este estudio fue aprobado por el Comité de Ética para el trato de animales de UNIFESO, en una reunión ordinaria celebrada el 30/03/2007. 
causes stress, which can affect the results obtained.

Immediately after venipuncture, blood was transferred to an eppendorf (Axygen) containing ethylene diamino-acid tetra-acetic acid (EDTA) (EDTA Vacutainer 26 BD). After the homogenization of blood with anticoagulant and the identification of eppendorf, the samples were processed in two locations: the entire count held in Newbauer Chamber (Boeco Germany) was made in the Aquário de Ubatuba and packed cell volume was sent in a private lab of the city, called MedLabor.

The eritrogram, with determination of red blood cell (hemocytometer) and packed cell volume (microhematocrit) was done using standard techniques and the leucogram, with determination only of white blood cell using the technique developed by Smith et al (6).

Ethical aspects. This study was approved by the Ethics Committee in dealing with Animals of UNIFESO, at the ordinary meeting held on $30 / 03 / 2007$.

\section{RESULTS}

The results obtained for hematological values of one male and three females of the species Zapteryx brevirostris relative to Red Blood Cell (RBC), Packed Cell Volume (PCV) and White Blood Cells (WBC) are described in tables 1 and 2 respectively.

Table 1. Hematological Parameters values of an exemplary male of the Zapteryx brevirostris species.

\begin{tabular}{lcccc}
\hline \multicolumn{1}{c}{ Animal } & Date & RBC & PCV & WBC \\
\hline$N^{\circ} 2$ & $10 / 04 / 2007$ & 0.54 & 30 & 46.2 \\
\hline RBC Red Blood Cell $\times 10^{6} / \mathrm{mm}^{3}$ & & & \\
WBC White Blood Cell $\times 10^{3} / \mu \mathrm{L}$ & & & \\
PCV Packed Cell Volume \% & & &
\end{tabular}

The results of the means for hematological values of species Zapteryx brevirostris pertaining to red blood cell, packed cell volume and white blood cell are described in table 3.

The animal's blood number 1 (female) has undergone coagulation immediately after contact with blood thinner, so that animal was not considered in the statistical analysis of the data. During the procedure of collecting the blood sample on this copy it was observed that the same exhibited signs of stress, which may have caused the clotting of the extracted sample.

\section{RESULTADOS}

Los resultados obtenidos para los valores hematológicos de un macho y tres hembras de la especie Zapteryx brevirostris relativos a los glóbulos rojos (GR), el volumen celular empaquetado (VCE) (hematocritos) y los glóbulos blancos (GB), se describen respectivamente en las tablas 1 y 2 .

Los resultados de la media de los valores hematológicos de las especies Zapteryx brevirostris pertenecientes a los glóbulos rojos, hematocrito y glóbulos blancos se describen en la tabla 3.

La sangre del animal № 1 (hembra) se coaguló inmediatamente después del contacto con el anticoagulante y por tanto este animal no se consideró en el análisis estadístico de los datos. Durante el procedimiento de toma de una segunda muestra de sangre se observó que exhibía signos de estrés, lo que pudo haber causado la coagulación de la muestra extraída.

El uso del anticoagulante EDTA demostró ser efectivo para su propósito cuando se utilizó en la toma de muestras de sangre de ejemplares de la especie Zapteryx brevirostris, con excepción del animal No 1.

Table 2. Hematological Parameters values of two females of the Zapteryx brevirostris species

\begin{tabular}{ccccc}
\hline Animal & Date & RBC & PCV & WBC \\
\hline No 3 & $06 / 04 / 2007$ & 1.48 & 20 & 28.2 \\
No 4 & $13 / 04 / 2007$ & 0.87 & 23 & 36.0 \\
\hline
\end{tabular}

RBC Red Blood Cell x $10^{6} / \mathrm{mm}^{3}$

WBC White Blood Cell $\times 10^{3} / \mu \mathrm{L}$

PCV Packed Cell Volume \%

Table 3. Hematological Parameters values for mean, standard deviation and range (minimummaximum) in Zapteryx brevirostris $(\mathrm{n}=3)$.

\begin{tabular}{ccccc}
\hline Variable & Mean & $\begin{array}{c}\text { Standard } \\
\text { deviation }\end{array}$ & $\begin{array}{c}\text { Lower } \\
\text { limit }\end{array}$ & $\begin{array}{c}\text { Upper } \\
\text { limit }\end{array}$ \\
\hline RBC & 0.96 & 0.48 & 0.4 & 1.5 \\
PCV & 24.3 & 5.1 & 18.6 & 30.1 \\
WBC & 36.8 & 9.03 & 26.6 & 47.0 \\
\hline
\end{tabular}

RBC Red Blood Cell x 106/ $\mathrm{mm}^{3}$

WBC White Blood Cell $\times 10^{3} / \mu \mathrm{L}$

PCV Packed Cell Volume \%

\section{DISCUSIón}

Los valores promedio de los glóbulos rojos para Zapteryx brevirostris que se encontraron en esta trabajo fueron de $0,96 \times 10^{6} / \mathrm{mm}^{3}$ con una desviación estándar de 0,48 , menor que la reportada por Rodrigues y colaboradores (7), la cual fue de $0,343 \times 10^{6} / \mathrm{mm}^{3}$ con una desviación 
The use of the anticoagulant EDTA proved to be effective in its purpose when they were used in blood samples collected from specimens of species Zapteryx brevirostris, with exception of the animal no 1 .

\section{DISCUSSION}

The average values of red blood cell for Zapteryx brevirostris found in this work was $0.96 \times 10^{6}$ / $\mathrm{mm}^{3}$ with standard deviation of 0.48 , less than reported by Rodrigues et al (7) which was of $0.343 \times 10^{6} / \mathrm{mm}^{3}$ with standard deviation of 0.058. If compared with other species of the same genus, as in the case of Rhinobatos horkelli, this difference increases, because the average red blood cell is $0.303 \times 10^{6} / \mathrm{mm}^{3}$, with standard deviation of 0.066 . In addition to this fact, the averages found by the authors are also not within the values of the lower limit and upper limit described in this work, which are respectively 0.4 $\times 10^{6} / \mathrm{mm}^{3}$ and $1.5 \times 10^{6} / \mathrm{mm}^{3}$ for red blood cell.

The value of the packed cell volume found on this work was $24.3 \%$ with a standard deviation of 5.1 while Wilhelm Filho et al (8) reported a packed cell volume value for the sort Zapteryx brevirostris of $19.0 \%$ with standard deviation of 5.7. Brito (9) studying 53 specimens of four species of the genus Potamotrygon have found an average of $21.5 \%$ with standard deviation between 0,81 and 4,6 and Rodrigues et al (7) described a mean value for the packed cell volume of species Rhinobatos percellens of $20.5 \%$ and standard deviation of 0.5 , greater than the value reported by Wilhelm Filho et al (8) to the packed cell volume $19.0 \%$ and standard deviation of 5.7 of species Zapteryx brevirostris. However, the averages of the values of packed cell volume (19.0\% and $20.5 \%$ ) cited by the authors are within the values of the range reported in this work are of $18.6 \%$ for the lower bound and $30.1 \%$ for the upper bound.

The average values for the white blood cell were not cited by any of the authors studied, thus the mean values found in this work, $36.8 \times 10^{3} / \mu \mathrm{L}$ for white blood cell average, standard deviation of 9.03 and the range of $26.6 \times 10^{3} / \mu \mathrm{L}$ for lower limit and $47.0 \times 10^{3} / \mu \mathrm{L}$ for upper bound cannot be analyzed once are unpublished values for this hematological parameters for the species of rays.

Due to the low number of animals from Aquarium of Ubatuba available for the study, which decreases the accuracy, the hematological findings of Zapteryx brevirostris in this research should be considered as preliminary. estándar de 0,058. Si se compara con otras especies del mismo género, como en el caso de Rhinobatos horkelli, esta diferencia aumenta, ya que el promedio de los glóbulos rojos es de $0,303 \times 10^{6} / \mathrm{mm}^{3}$, con una desviación estándar de 0,066. Además de este hecho, los promedios encontrados por los autores, por tanto, no se encuentran dentro de los valores del límite inferior y límite superior descritos en este trabajo, que son $0,4 \times 10^{6} / \mathrm{mm}^{3}$ y $1,5 \times$ $10^{6} / \mathrm{mm}^{3}$ respectivamente, para glóbulos rojos.

El valor del hematocrito que se encuentra en este estudio fue de $24,3 \%$, con una desviación estándar de 5,1, mientras que Wilhelm Filho y colaboradores (8) reportaron un valor de hematocritos para la clase Zapteryx brevirostris de $19,0 \%$ con una desviación estándar de 5,7. Brito (9), en el estudio de 53 ejemplares de cuatro especies del género Potamotrygon, encontró un promedio de $21,5 \%$ con una desviación estándar entre 0,81 y 4,6 y Rodrigues y colaboradores (7) describieron un valor medio para el volumen de hematocritos de las especies Rhinobatos percellens de 20,5\% y una desviación estándar de 0,5 , mayor que el valor reportado por Wilhelm Filho y colaboradores (8) con hematocritos de $19,0 \%$ y una desviación estándar de 5,7 para la especie Zapteryx brevirostris. Sin embargo, el promedio de los valores de los hematocritos (19,0\% y 20,5\%) citado por los autores, se encuentra dentro de los valores del rango reportado en este trabajo que son de $18,6 \%$ para el límite inferior y de 30,1\% para el límite superior.

Los valores promedio de glóbulos blancos no fueron citados por ninguno de los autores estudiados, por lo que los valores medios que se encontraron en este trabajo fueron de $36,8 \times 10^{3}$ / $\mu$ l para los glóbulos blancos en promedio, con una desviación estándar de 9,03 y un rango de $26,6 \times 10^{3} / \mu$ l para el límite inferior y de 47,0 x $10^{3}$ / $\mu$ l para el límite superior, no pudieron ser analizados debido a que son valores inéditos de esos parámetros hematológicos para las especies de rayas.

El bajo número de animales en el Acuario de Ubatuba disponibles para el estudio disminuye la precisión, los hallazgos hematológicos para Zapteryx brevirostris en esta investigación deben ser considerados como preliminares.

Los rangos de referencia reportados en este estudio son de importancia científica, debido al hecho de que la Zapteryx brevirostris se encuentra en una situación de vulnerabilidad y se pueden utilizar para ayudar en el manejo de 
The reference ranges reported in this study are of scientific importance, due to the fact that the Zapteryx brevirostris be in a situation of vulnerability, and can be used to aid in the management of aquarium stingrays and to create a baseline for health monitoring of the Zapteryx brevirostris wild.

The results show that further studies should be made to better techniques of data collection and standardization of hematological parameters. las rayas en el acuario y para la creación de una línea de base para vigilar la salud de la Zapteryx brevirostris en estado salvaje.

Los resultados muestran que se deben efectuar más estudios para mejorar las técnicas de recolección de datos y la estandarización de los parámetros hematológicos.

\section{REFERENCES}

1. Gonzalez MMB. Censo sul-americano de elasmobrânquios em cativeiro: tubarões e raias como recursos para pesquisa e educação. Panam J Aquat Sci 2006; 1(1):11-19.

2. Santos C, Cortellete GM, Araújo KCB, Spach $\mathrm{HL}$. Estrutura populacional da raia-viola Zapteryx brevirostrisostris (Chondrichthyes, Rhinobatidae), na plataforma adjacente à Baia de Paranaguá, P.R., 1977. Acta Biol Leopoldensia 2006; 28(1):32-37.

3. Marion C, Vaske-Junior T, Gadig OBF, Martins IA. Feeding habits of the shortnose guitarfish, Zapteryx brevirostris (Müller and Henle, 1841) (Elasmobranchii, Rhinobatidae) in southeastern Brazil. Braz J Biol 2011; 71(1):83-89.

4. Hrubec TC, Smith SA. Hematology of Fish. In: Feldman BF, Zinkl JG, Jain NC. Schalm's Veterinary Hematology. $5^{\text {a }}$ ed. Philadelphia: Lippincott Williams \& Wilkins; 2000.

5. Oliveira AT, Lemos JRG, Santos MQ de $C$, Pereira C do N, Dias MT, Marcon JL. Parâmetros sanguíneos da arraia de água doce Potamotrygon orbignyi Castelnau, 1855 (Potamotrygonidae) da Bacia do Rio Negro, Amazonas, Brasil. [online] EMBRAPA; 2010. URL available in: https://www.embrapa.br/amapa/buscade-publicacoes/-/publicacao/878613/ parametros-sanguineos-da-arraia-de-aguadoce-potamotrygon-orbignyi-castelnau1855-potamotrygonidae-da-bacia-do-rionegro-amazonas-brasil
6. Smith M, Warmolts D, Thoney D, Hueter R. The Elasmobranch Husbandry Manual:Captive Care of Sharks, Rays and their Relatives. Special Publication Special Publication of the Ohio Biological Survey. 2004.

7. Rodrigues E, Medeiros A, Rosa R, Bacila M. Carbohydrate Metabolism in fish erythrocytes: blood glucose compartmentalization. Arch Veterinary Sci 1989; 4(1):99-102.

8. Wilhelm Filho DW, Eble GJ, Kassner G, Caprario FX, Dafré AL, Ohira M. Comparative Hematology in Marine Fish. Comp Biochem Physiol 1992; 102A(2):311-321.

9. Brito FMM. Variáveis hematológicas, hormonais, bioquímicas séricas e fauna parasitária em quatro espécies de raias do gênero Potamotrygon Garman, 1877 (Myliobatiformes, Potamotrygonidae) de vida livre. [Tese de Doutorado]. JaboticabalSão Paulo: Universidade Estadual Paulista, Faculdade de Ciências Agrárias e Veterinárias; 2012. 